Article

\title{
Biocompatibility and Antibacterial Properties of ZnO-Incorporated Anodic Oxide Coatings on TiZrNb Alloy
}

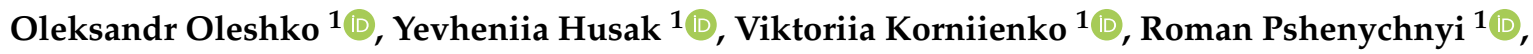 \\ Yuliia Varava ${ }^{1}$, Oksana Kalinkevich ${ }^{2}{ }^{(0)}$, Marcin Pisarek ${ }^{3}{ }^{(0)}$, Karlis Grundsteins ${ }^{4}$, \\ Oksana Pogorielova ${ }^{1}$, Oleg Mishchenko ${ }^{5}$, Wojciech Simka ${ }^{5,6, *(D)}$, Roman Viter 1,4,* \\ and Maksym Pogorielov 1,5,*(D) \\ 1 Medical Institute, Sumy State University, 40018 Sumy, Ukraine; oleshkosanya007@gmail.com (O.O.); \\ evgenia.husak@gmail.com (Y.H.); vicorn77g@gmail.com (V.K.); pshenychnyi@gmail.com (R.P.); \\ yuliia.varava@gmail.com (Y.V.); o.s.pogorielova@gmail.com (O.P.) \\ 2 Institute of Applied Physics NASU, 40000 Sumy, Ukraine; oksana.kalinkevich@gmail.com \\ 3 Institute of Physical Chemistry PAS, 01-224 Warsaw, Poland; mpisarek@ichf.edu.pl \\ 4 Institute of Atomic Physics and Spectroscopy, University of Latvia, LV-1586 Riga, Latvia; \\ karlis.grundsteins@gmail.com \\ 5 NanoPrime, 39-200 Dębica, Poland; dr.mischenko@icloud.com \\ 6 Faculty of Chemistry, Silesian University of Technology, 44-100 Gliwice, Poland \\ * Correspondence: wojciech.simka@polsl.pl (W.S.); roman.viter@lu.lv (R.V.); m.pogorielov@gmail.com (M.P.); \\ Tel.: +48-32-237-2605 (W.S.)
}

Received: 24 October 2020; Accepted: 27 November 2020; Published: 30 November 2020 updates

\begin{abstract}
In a present paper, we demonstrate novel approach to form ceramic coatings with incorporated $\mathrm{ZnO}$ nanoparticles (NPs) on low modulus TiZrNb alloy with enhanced biocompatibility and antibacterial parameters. Plasma Electrolytic Oxidation (PEO) was used to integrate $\mathrm{ZnO}$ nanoparticles (average size $12-27 \mathrm{~nm}$ ), mixed with $\mathrm{Ca}\left(\mathrm{H}_{2} \mathrm{PO}_{2}\right)_{2}$ aqueous solution into low modulus TiZrNb alloy surface. The TiZrNb alloys with integrated $\mathrm{ZnO}$ NPs successfully showed higher surface porosity and contact angle. XPS investigations showed presence of $\mathrm{Ca}$ ions and absence of phosphate ions in the PEO modified layer, what explains higher values of contact angle. Cell culture experiment (U2OS type) confirmed that the surface of as formed oxide-ZnO NPs demonstrated hydrophobic properties, what can affect primary cell attachment. Further investigations showed that Ca ions in the PEO coating stimulated proliferative activity of attached cells, resulting in competitive adhesion between cells and bacteria in clinical situation. Thus, high contact angle and integrated $\mathrm{ZnO} N P s$ prevent bacterial adhesion and considerably enhance the antibacterial property of TiZrNb alloys. A new anodic oxide coating with ZnO NPs could be successfully used for modification of low modulus alloys to decrease post-implantation complications.
\end{abstract}

Keywords: $\mathrm{ZnO}$ nanoparticles; $\mathrm{TiZrNb}$ alloy; plasma electrolytic oxidation; cell culture; antibacterial properties

\section{Introduction}

Dental and orthopedic implants fulfil to specific requirements, such as high strength, low density, excellent corrosion resistance, high biocompatibility, and ability to osteointegration. Elastic stiffness is an important parameter that predicts load transfer between implant and surrounding bones. Most implants are still made of Ti alloys with elastic module (Young modulus) above $100 \mathrm{GPa}$. Their load transfer could lead to osteoporosis due to mechanical mismatch [1]. The implants with both 
high strength and a low Young's modulus (close to bone values-16-20 GPa) are required for dental applications [2]. It has been demonstrated that decreasing of elastic modulus minimized the bone atrophy due to reduction of stress shielding bone resorption and prevented implant loosening $[3,4]$. Metastable beta Ti-based alloys are the best candidates for dental and orthopedic implant development due to superelastic effect (high recoverable strain) and a very significant reduction of the apparent elastic modulus [5]. Beta-titanium alloys such as metastable TiNb exhibit significantly low apparent elastic modulus and demonstrate promising results on in-vitro and in-vivo research [6]. Maity et al. developed Ti-35Nb-7Zr-5Ta alloy with low Young's modulus (E 68 GPa) and high flow strength ( $\sigma \mathrm{f} \sim 1 \mathrm{GPa}$ ) with uniform hardness distribution without any noticeable change in the strength of the material [5]. Nune et al. reported on high bioactivity of Ti-24Nb-4Zr-8Sn alloy ( 49 GPa), including ability of osteoblast's stimulation [7]. Previously, we developed and investigated new TiZrNb system with extremely low Young's module equal 34.85 GPa with high biocompatibility [8].

Mechanical properties of implants play important role in a long-term exploitation period. It requires active surface for successful osteointegration in early post-implantation time-point. The implant surface parameters such as chemical composition and roughness provide significant influence to protein adsorption, precipitation of bone minerals, and stimulation of cells growth after implantation [9]. Calcium-phosphate coatings demonstrate significant improvement of osteointegration due to direct osteoblast stimulation and collagen adhesion [10]. However, current deposition methods show short-term stability and frequent implant failures [11]. Additionally to osteointegrative potential, implant surface should provide protection from bacteria adhesion and biofilm formation for prevention of infectious complications [12]. Recently, metal and metal oxide nanoparticles are actively used to provide antibacterial properties of implant calcium-phosphate coating [13-16]. Silver is the most known metal with high antibacterial properties that demonstrates significant reduction of bacteria adhesion in numerous researches $[13,14]$. But side-effects, including cell toxicity and tissue accumulation $[15,16]$ require development of new strategy to balance antibacterial properties and osteointegration potentials. Zinc and zinc oxide are promising candidates due to significant antibacterial and osteogenic properties [17-19]. Zn exhibits promotion of specific osteoblast gen markers and stimulates mineralization via the deposition of calcium in mesenchymal stem cells [17]. Some reports suggested that Zn nanoparticles (ZnNPs)-decorated implant surface demonstrate increasing initial cell adhesion, spreading and proliferation [18,19]. At the same time, ZnNPs demonstrate moderate antibacterial properties due to direct cell-NPs interaction and Reactive Oxygen Species (ROS) evolution [20]. Recently, Ag/ZnO-hydroxyapatite coating deposited by laser cladding demonstrated prevention of bacteria adhesion and stimulation of the new bone tissues formation in-vivo [17]. Other study demonstrated that $\mathrm{ZnO} /$ polydopamine (PDA)/arginine-glycine-aspartic acid-cysteine coatings exhibit both antibacterial and osteogenic potential [21]. Authors confirmed that controlled release of $\mathrm{Zn}$ ions from coating could be an ideal solution for balancing osteogenic/antibacterial strategy.

Plasma Electrolytic Oxidation (PEO) is a quite new promising method for formation of stable ceramic coatings containing calcium phosphates on titanium and its alloys [22]. The main advantage of the PEO process is formation of good quality coatings on samples with complex shapes. The coatings are composed of substrate oxides and incorporated compounds from electrolyte [23,24]. It is possible to incorporate insoluble compounds/particles directly into the coating from electrolyte [25]. In our previous papers we proved fabrication of bioactive and antibacterial oxide coatings on $\mathrm{Ti}$ or $\mathrm{ZrNb}$ alloy with incorporation of nanoparticles [26-28]. PEO process provides formation of stable coating resistant to corrosion with slow ion release [26].

In a present paper, we demonstrate novel approach to form anodic ceramic coatings with incorporated $\mathrm{ZnO}$ NPs on low modulus TiZrNb alloy. The obtained coatings show both antibacterial and osteogenic effect. 


\section{Materials and Methods}

\subsection{Chemicals}

The TiZrNb alloy (NanoPrime (Dębica, Poland) with a height of $6 \mathrm{~mm}$ and $6 \mathrm{~mm}$ diameter was used in experiment [8]. All chemicals for $\mathrm{ZnO} N$ Ps synthesis and PEO process $\left(\mathrm{Zn}\left(\mathrm{CH}_{3} \mathrm{COO}\right)_{2} \cdot 2 \mathrm{H}_{2} \mathrm{O}\right.$, Ethylene glycol, $\mathrm{Ca}\left(\mathrm{H}_{2} \mathrm{PO}_{2}\right)_{2}$ ) have been purchased from Sigma Aldrich (Darmstadt, Germany) and used as received. Staphylococcus aureus and Esherihia coli, obtained from the Bacteria Collection of Sumy State University (Sumy, Ukraine), were used in bacteriological experiment. All bacteriological media were taken from HiMedia (Maharashtra, India) and Alamar blue was from Invitrogen (Carlsbad, CA, USA). For the cell culture study, all media and reagents were purchased from Gibco ${ }^{\circledR}$, Gaithersburg, MD, USA.

\subsection{Synthesis and Characteerization of $\mathrm{ZnO}$ Nanoparticles}

Nanoparticles were synthesized by polyol synthesis. Ethylene glycol (EG) was used as the reaction medium. $2.195 \mathrm{~g}$ of $\mathrm{Zn}\left(\mathrm{CH}_{3} \mathrm{COO}\right)_{2} \cdot 2 \mathrm{H}_{2} \mathrm{O}$ salt was dissolved in $10 \mathrm{~mL}$ of EG in a three-necked flask. A thermocouple, connected to a heating mantle with magnetic stirring, was placed in the flask with a reflux condenser.

The resulting solution was heated with vigorous stirring with a Teflon stirrer. After reaching a temperature of $160^{\circ} \mathrm{C}$, the mixture was kept for $60 \mathrm{~min}$. Nanostructured zinc oxide was formed as a result of the decomposition reaction of the zinc acetate:

$$
\mathrm{Zn}\left(\mathrm{CH}_{3} \mathrm{COO}\right)_{2} \cdot 2 \mathrm{H}_{2} \mathrm{O} \rightarrow \mathrm{ZnO}+2 \mathrm{CH}_{3} \mathrm{COOH}+\mathrm{H}_{2} \mathrm{O}
$$

The mixture was cooled to room temperature and the synthesized product was separated from the organic component (EG) by centrifugation. EG residues were washed with ethanol with vigorous shaking followed by centrifugation. The washing operation was repeated three times. Schematically, the process of obtaining $\mathrm{ZnO}$ can be represented by the following Scheme 1:

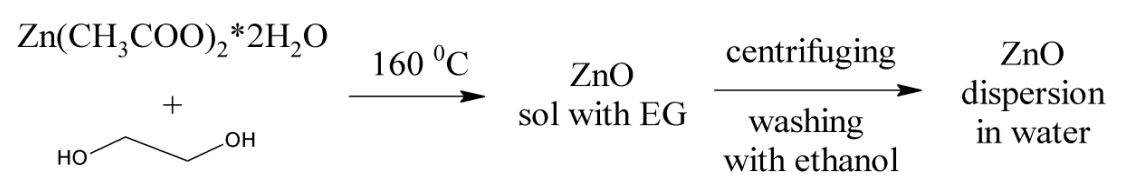

Scheme 1. The $\mathrm{ZnO}$ nanoparticle synthesis process.

\subsection{Plasma Electrolytic Oxidation (PEO)}

The surface area of the modified TiZrNb alloy was equal to $0.28 \mathrm{~cm}^{2}$. The samples were anodized in $\mathrm{Ca}\left(\mathrm{H}_{2} \mathrm{PO}_{2}\right)_{2}(0.5 \mathrm{M})$ electrolyte without and with $\mathrm{ZnO}$ nanoparticles $(40 \mathrm{~g} / \mathrm{L})$. PEO of the samples surface was realized via DC galvanostatic anodization (anodic current density $=150 \mathrm{~mA} / \mathrm{cm}^{2}$ ) using a DC power supply (PWR 800H, Kikusui, Japan) at a limiting voltage of 300-500 V for 5 min [26]. The samples were marked as TiZr-X for $\mathrm{Ca}\left(\mathrm{H}_{2} \mathrm{PO}_{2}\right)_{2}$ electrolyte and TiZr-X-ZnO for electrolyte with $\mathrm{ZnO}$ NPs, where $\mathrm{X}$ is the limiting voltage.

\subsection{Surface Analysis}

Scanning electron microscopy (SEM), energy-dispersive X-ray (EDX), X-ray photoelectron spectroscopy, and contact angle (CA) methods were used for structural and surface characterization of the modified surface. Details of these experiments were detailed described in our previous paper [26].

To investigate a thickness of the coatings formed during the PEO process, the cross-sections analysis tests of the oxide layers were performed. The samples were embedded in epoxy resin (Eposir F 740 + Ipox EH 2260) and then placed in a vacuum unit for 3 min before drying overnight. The grinding machine (Einhell TH-US 400) with $1440 \mathrm{rpm}$ was used to prepare cross-sections by 
using abrasive paper (Hermes BW114) with 400, 1000, 1200, and 1500 granulation. SEM images of cross-sections were obtained by using scanning electron microscopy (SEO-SEM Inspect S50-B (FEI, Brno, Czech Republic; accelerating voltage- $15 \mathrm{kV}$ ). To assess the chemical composition of the PEO layers, an energy-dispersive X-ray spectrometer (AZtecOne with X-MaxN20, Oxford Instruments plc, Abingdon, UK) accompanied by SEM was used.

Optical properties of non-treated and PEO coated TiZrNb samples were studied by photoluminescence spectroscopy in the range of 350-800 nm. Ultraviolet Nd:YAG laser $(266 \mathrm{~nm}$, output power $27 \mathrm{~mW}$, CNIlaser, Changchun, China) was used for photoluminescence excitation. HR4000 Ocean Optic spectrometer (Orlando, FL, USA) was used for detection of photoluminescence.

\subsection{Antibacterial Assessment}

The Staphylococcus aureus (S. aureus, B 918) obtained from the National Collection of Microorganisms (D.K. Zabolotny Institute of Microbiology and Virology, Kyiv, Ukraine) was cultivated on nutrient agar for $24 \mathrm{~h}$. The suspensions of overnight strain were mixed with nutrient broth medium, and the final concentration of microorganisms was adjusted to $10^{6} \mathrm{CFU}$ using a McFarland standard.

The minimum inhibitory concentration (MIC) and minimum bactericidal concentration (MBC) were evaluated before PEO deposition of ZnO-NPs by using the serial dilution method. ZnO-NPs (initial concentration $3 \mathrm{~g} / \mathrm{L}$ ) were diluted in each well of sterile 24-well plastic plate to have dilutions 1:2:4:8 etc. Then, $100 \mu \mathrm{L}$ of bacteria suspension was added to each well to reach $10^{5} \mathrm{CFU} / \mathrm{mL}$. The test and control samples (bacterium suspension alone) were incubated under shaking conditions (Mini Rocker-Shaker, BioSan MR-1, Riga, Latvia) at $37^{\circ} \mathrm{C}$ for $24 \mathrm{~h}$. Afterwards, $10 \mu \mathrm{L}$ of suspension from the wells with no visible bacterial growth (MIC) were cultivated on Mueller-Hinton's agar plates at $37^{\circ} \mathrm{C}$ for $24 \mathrm{~h}$ to evaluate MBC.

Antibacterial parameters of $\mathrm{ZrTiNb}$ PEO coated discs assessed with time-dependent adhesion test. For this purpose, samples were immersed horizontally in $2 \mathrm{~mL}$ bacterial suspension with a concentration $10^{5} \mathrm{CFU} / \mathrm{mL}$ and statically incubated for $2,4,6$, and $24 \mathrm{~h}$ aerobically at $37^{\circ} \mathrm{C}$. At each time point, the disks were washed three times with phosphate buffer saline (PBS; $\mathrm{pH}=7.4$ ) to remove medium and planktonic bacterial cells. Then samples were placed individually in tubes with sterile saline and were ultrasonicated for $1 \mathrm{~min}$ in an ultrasonic bath (B3500S-MT, Bransone Ultrasonics Co., Shanghai, China) followed by vortex mixing (Mini Rocker-Shaker, BioSan MR-1, Riga, Latvia). $10 \mu \mathrm{L}$ aliquots of each sonicated liquid were pipetted out and spread onto Mueller-Hinton's agar plates using the streak plate technique. The plates were incubated at $37^{\circ} \mathrm{C}$ for $24 \mathrm{~h}$. The number of adhering viable microorganisms was assessed by counting the colonies. All the measurements were triplicated.

\subsection{Cell Culture}

The cells (U2OS cell type) were grown in $75 \mathrm{~cm}^{2}$ cell culture flasks under standard culture conditions of humidified air containing $5 \% \mathrm{CO}_{2}$ at temperature $37^{\circ} \mathrm{C}$ with medium renewal every 2-3 days. Dulbecco's modified Eagle medium/nutrient mixture F-12 (DMEM/F-12) with L-glutamine was used, containing $100 \mathrm{units} / \mathrm{mL}$ penicillin, $100 \mu \mathrm{g} / \mathrm{mL}$ streptomycin, $2.5 \mu \mathrm{g} / \mathrm{mL}$ amphotericin $\mathrm{B}$ and $10 \%$ fetal bovine serum. Experiments were performed as described before [26]. After sterilization samples were placed in a separate well of 24-well cell culture plate and immersed in DMEM overnight. U2OS cells were seeded on each sample and in the wells without samples (as positive control) with the cell density of $10^{4}$ cells per well. Cell adhesion and proliferation on samples were assessed by the Alamar blue colorimetric assay as following: the plates were incubated for $8 \mathrm{~h}$ at $37^{\circ} \mathrm{C}$ in the dark and then medium was added. In next step, medium was transferred to another 96-well plate, and the absorbance was measured by using a Multiskan FC (Thermo Fisher Scientific, Waltham, MA, USA) plate reader at wavelengths of 570 and $595 \mathrm{~nm}$. The cells were quantified at different time intervals: 1 , 3 , and $7 \mathrm{~d}$. All experiments were repeated three times.

All experiments with cell culture were approved by Institutional Bioethics Committee (Sumy State University, protocol 5/25 from 8 May 2019). 
The statistical analysis of obtained results was based on one-way analysis of variance (GraphPad Prism 8.0 software), and $p$ value of less than 0.05 was considered to be statistically significant and detailed described in [26].

\section{Results and Discussion}

\subsection{ZnO NPs Characterization}

The results of XRD analysis of the synthesized sample dried at $80{ }^{\circ} \mathrm{C}$ for $12 \mathrm{~h}$ showed that well-crystallized zinc oxide of the hexagonal modification (space group P63mc) was formed (Figure 1A). The characteristics of the diffraction peaks of the synthesized $\mathrm{ZnO}$ correspond to the JCPDS card No. 01-089-1397.
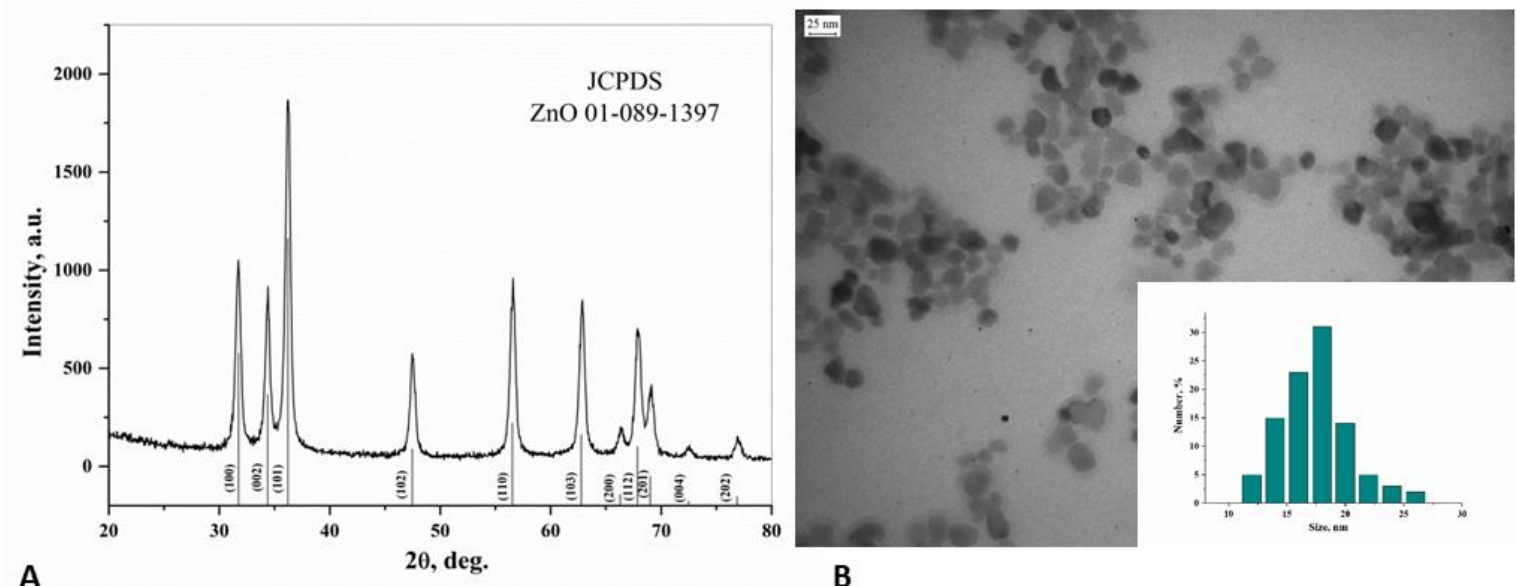

B

Figure 1. Diffraction pattern (A) and TEM image (B) size distribution (insertion) of $\mathrm{ZnO}$ nanocrystals.

The average size of $\mathrm{ZnO}$ was calculated from the physical broadening of the diffraction peak (102) using the equation:

$$
L=\frac{0.94 \lambda}{\beta \cos \theta},
$$

where $\lambda$ is the $\mathrm{x}$-ray diffraction wavelength; $\beta$ is the value of the physical broadening of the corresponding diffraction peak; $\theta$-diffraction angle. Crystalline size of $\mathrm{ZnO}$ was $13.6 \pm 5 \mathrm{~nm}$.

The calculated unit cell parameters of the synthesized zinc oxide were $a=0.32476 \mathrm{~nm}$, $c=0.52095 \mathrm{~nm}$, and the value of elementary cell volume was $V_{\text {cell }}=0.0549 \mathrm{~nm}^{3}$.

Analysis of TEM microscopy images showed that the synthesized nanoparticles had a spherical shape with sizes in the range of 12-27 nm (Figure 1B).

$\mathrm{ZnO}$ nanoparticles have shown their effectiveness against $S$. aureus strain (MIC and MBC were $0.375 \mathrm{~g} / \mathrm{L}$ and $0.1875 \mathrm{~g} / \mathrm{L}$, respectively).

\subsection{Surface Analysis of PEO Ceramic Coatings}

Scanning electron microscopy demonstrates formation of a thick homogeneous oxide layer on TiZrNb samples after PEO in $\mathrm{Ca}\left(\mathrm{H}_{2} \mathrm{PO}_{2}\right)_{2}$ electrolyte bath (Figure 2). The thickness of PEO coating significantly decreased from $29.7 \pm 6.3 \mu \mathrm{m}$ at $300 \mathrm{~V}$ mode to $14.85 \pm 5.8 \mu \mathrm{m}$ at $450 \mathrm{~V}$ (Figure 2). The surface was covered by an oxide layer, containing small round-shaped pores and craters with various sizes. Figures 2 and 3 demonstrate that surface structure, pore growth and pore size distribution strongly depend on PEO regimens (voltage applied). The surface porosity significantly grew from $7.46 \pm 0.54 \%$ to $10.11 \pm 1.2$ with increasing voltage. The addition of ZnO NPs leads to significant growth of oxide layer thickness from $37.8 \pm 5.3 \mu \mathrm{m}$ at $350 \mathrm{~V}$ to $45.9 \pm 3.7 \mu \mathrm{m}$ at $500 \mathrm{~V}$ regime. Surface morphology after PEO with ZnO NPs is shown in Figure 2. Irregular elongated large pores 
with numerous round-shaped small pores have been identified (Figure 2). The increase of voltage led to decreasing of small pores number and increasing of elongated pore size (Figure 3). Opposite to basic $\mathrm{Ca}\left(\mathrm{H}_{2} \mathrm{PO}_{2}\right)_{2}$ electrolyte, addition of $\mathrm{ZnO}$ NPs led to dramatically increasing porosity from $10.30 \pm 2.4 \%$ at $350 \mathrm{~V}$ mode to $24.39 \pm 6.2 \%$ at $400 \mathrm{~V}$ followed by porosity reduction to $13.35 \pm 3.9 \%$ and $11.08 \pm 4.3 \%$ at higher voltages. Pore size and porosity were the main parameters responsible to cell attachment and proliferation. It was found that increasing of pore size significantly facilitate bone cell migration and proliferation [29,30] as well as cell biochemical activity (ALP and collagen production) [31]. On the other hand, the mesoporous surface could provide more natural environment for cell attachment and proliferation, and ZnO NPs solution provides formation of hierarchical architecture surface on TiZrNb alloy.

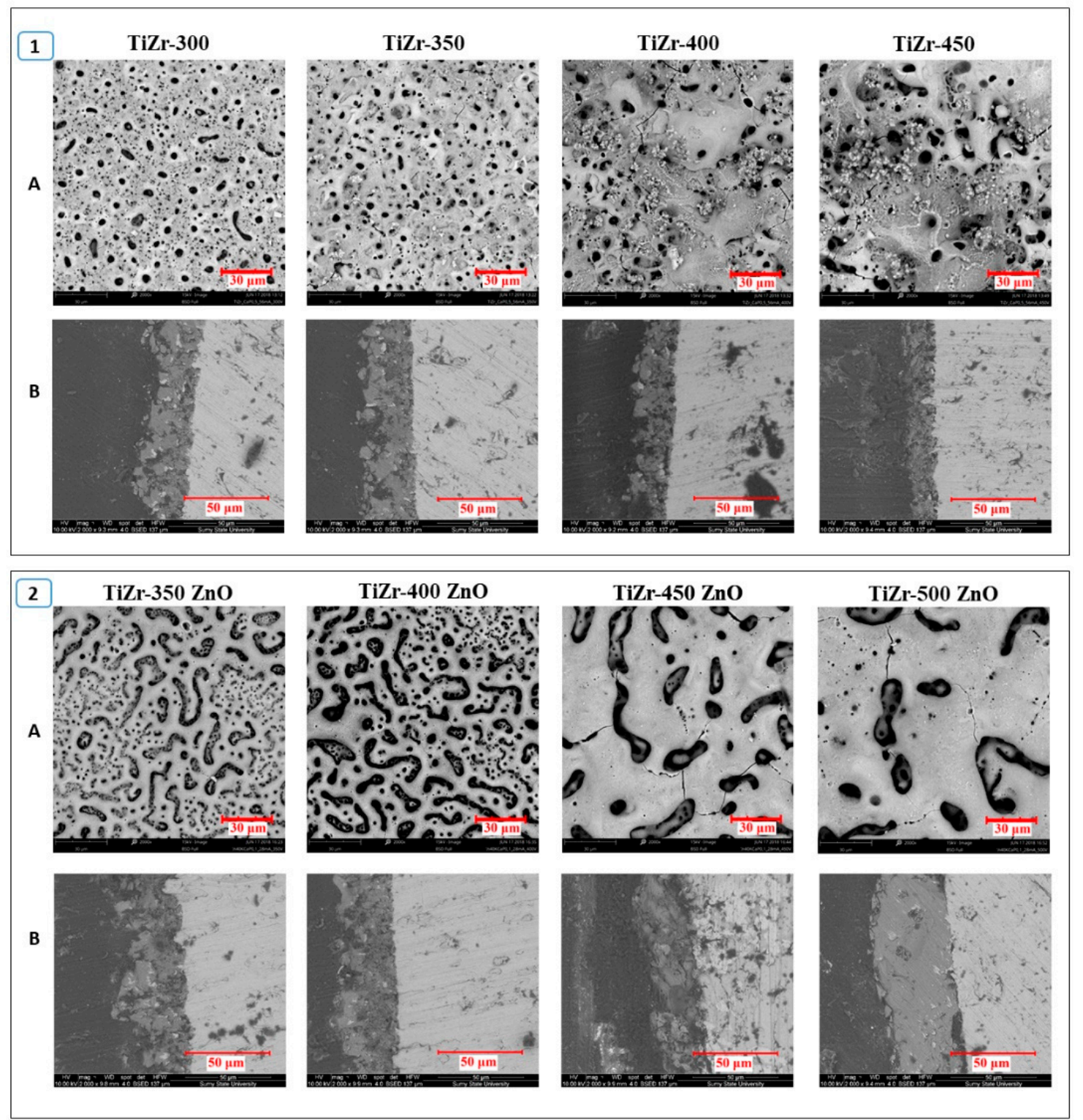

Figure 2. The SEM images microscopy of oxide layer (A) and cross-section (B) of Plasma Electrolytic Oxidation (PEO)-treated implants in $\mathrm{Ca}\left(\mathrm{H}_{2} \mathrm{PO}_{2}\right)_{2}$ electrolyte bath (1) and with $\mathrm{ZnO}$ nanoparticles (NPs) (2). 


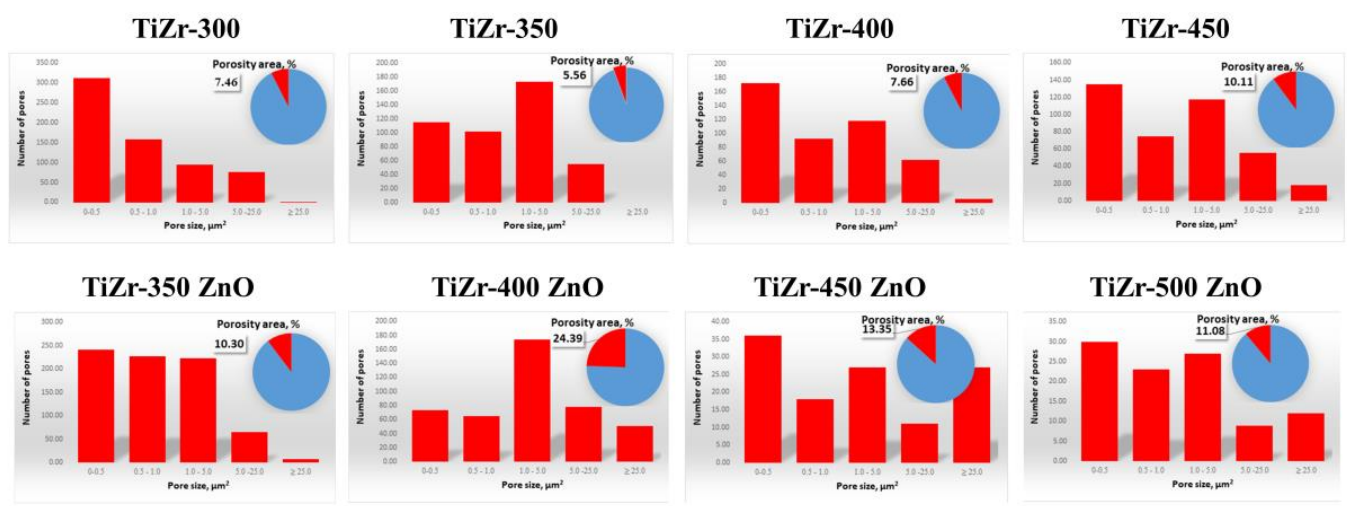

Figure 3. The pore size distribution of PEO-treated implants in $\mathrm{Ca}\left(\mathrm{H}_{2} \mathrm{PO}_{2}\right)_{2}$ electrolyte bath (upper row) and with $\mathrm{ZnO}$ NPs (low row).

EDX analysis showed that increasing voltage up to $400 \mathrm{~V}$ had no effect to amount of titanium, zirconium, calcium and phosphorus content in the oxide layer formed in $\mathrm{Ca}\left(\mathrm{H}_{2} \mathrm{PO}_{2}\right)_{2}$ electrolyte (Table 1). Decrease of concentration of titanium, calcium and phosphorus and increase of concentration of zirconium to $3.5 \%$ was observed at higher voltages. Atomic ratio of $\mathrm{Ca} / \mathrm{P}$ increased from 1.1 to 1.3 , similarly to the $\mathrm{Ca} / \mathrm{P}$ atomic ratio in hydroxyapatite [32]. Incorporation of $\mathrm{ZnO}$ nanoparticles to the implant surface affected the concentrations of elements ( $\mathrm{Ca}, \mathrm{P}, \mathrm{Zr}, \mathrm{Ti}, \mathrm{Zn})$ (Table 1). The $\mathrm{ZnO}$ content was $7 \%$ for low voltages $(350-400 \mathrm{~V})$ and $10 \%$ for high voltages $(450-500 \mathrm{~V}) \mathrm{The} \mathrm{Ca} / \mathrm{P}$ ratio was independent of voltage- $-0.4-0.6$. Niobium was not detected in all cases due to low concentration in the oxide layers.

Table 1. The semi-quantitative EDX analysis of PEO coatings.

\begin{tabular}{|c|c|c|c|c|c|c|c|}
\hline & \multicolumn{6}{|c|}{ Atomic Concentration, \% } & \multirow{2}{*}{$\mathrm{Ca} / \mathrm{P}$ Ratio } \\
\hline & $\mathbf{O}$ & $\mathrm{Ca}$ & $\mathbf{P}$ & $\mathbf{T i}$ & $\mathrm{Zr}$ & $\mathrm{Zn}$ & \\
\hline TiZr-300 & 68.6 & 14.7 & 13.3 & 1.8 & 1.6 & - & 1.1 \\
\hline TiZr-350 & 68.7 & 14.8 & 13.6 & 1.5 & 1.5 & - & 1.1 \\
\hline TiZr-400 & 70.0 & 14.2 & 13.2 & 1.2 & 1.4 & - & 1.1 \\
\hline TiZr-450 & 71.7 & 13.3 & 10.4 & 1.2 & 3.5 & - & 1.3 \\
\hline TiZr-350 ZnO & 68.6 & 4.3 & 9.9 & 3.7 & 7.1 & 6.5 & 0.4 \\
\hline TiZr-400 ZnO & 70.1 & 3.9 & 9.5 & 3.2 & 6.8 & 6.5 & 0.4 \\
\hline TiZr-450 ZnO & 67.6 & 5.4 & 9.4 & 2.1 & 5.8 & 9.7 & 0.6 \\
\hline TiZr-500 ZnO & 68.2 & 5.2 & 9.8 & 2.1 & 4.7 & 9.9 & 0.5 \\
\hline
\end{tabular}

Figure 4 shows distribution of elements in the oxide layers formed in $\mathrm{Ca}\left(\mathrm{H}_{2} \mathrm{PO}_{2}\right)_{2}$ electrolyte (upper row) and after addition of ZnO NPs (low row). We can confirm uniform distribution of $\mathrm{Ca}, \mathrm{P}$, and $\mathrm{Zn}$ (in the case of second electrolyte) in whole volume of the coatings. 

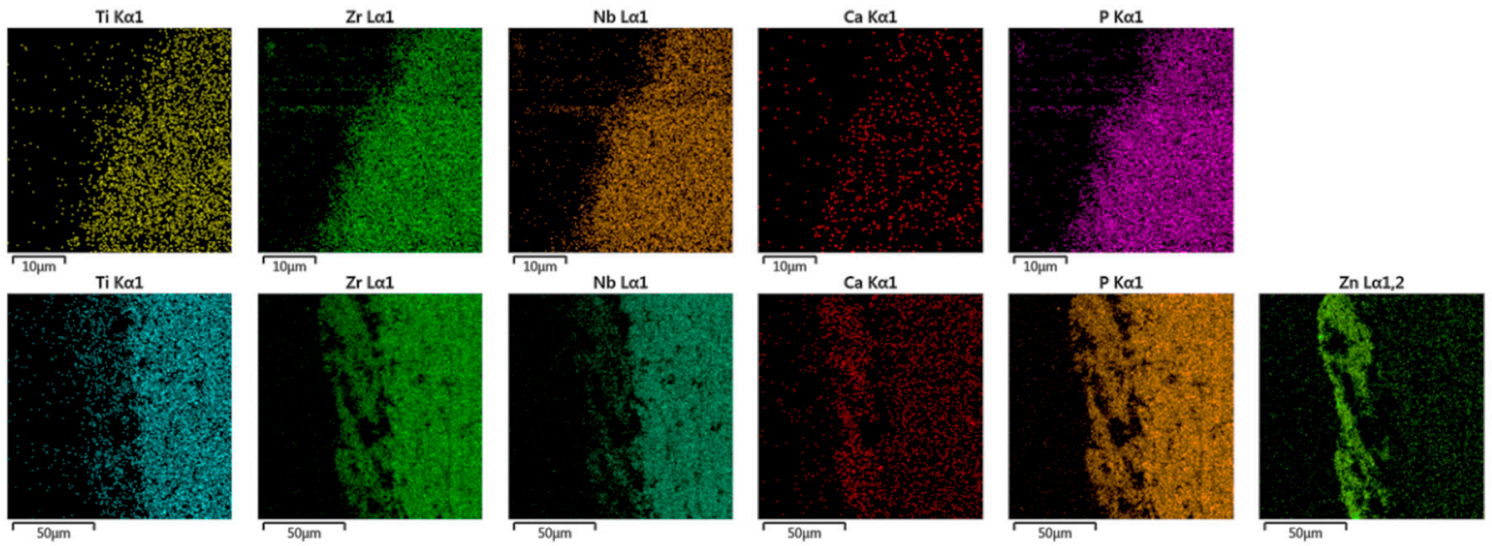

Figure 4. Exemplary EDX mapping of TiZrNb alloy cross-sections after $\mathrm{PEO}$ in $\mathrm{Ca}\left(\mathrm{H}_{2} \mathrm{PO}_{2}\right)_{2}$ electrolyte without (upper row) and with addition of $\mathrm{ZnO}-\mathrm{NPs}$ (low row).

The PEO coatings formed on the TiZrNb alloy were analyzed by using an XPS technique. XPS results are summarized in Figures 5 and 6 and Table 2.
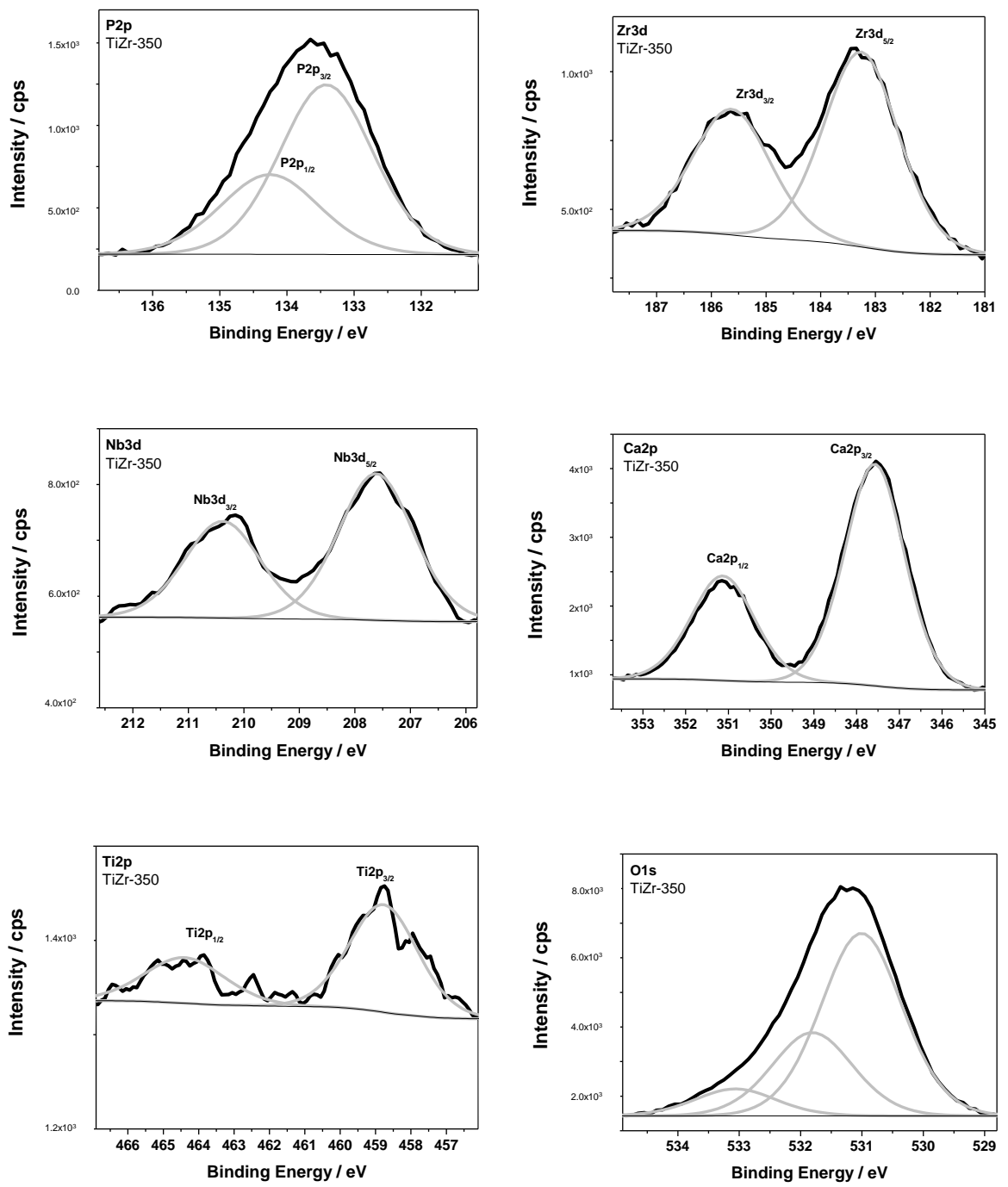

Figure 5. The high resolution XPS spectra after the deconvolution procedure, sample TiZr-350. 
Table 2 shows the binding energies of Ti2p3/2, Zr3d5/2, Nb3d5/2, Zn2p3/2, P2p3/2, Ca2p3/2 and O1s signals registered at the surface of TiZr-350 and TiZr-350-ZnO samples after deconvolution procedure. The measured XPS spectra for metallic elements were characteristic for oxides. Therefore, it was found that the signals at each individual binding energies could be attributed to titanium oxide $\left(458.8 \mathrm{eV}-\mathrm{TiO}_{2}\right)$, zirconium oxide $\left(183.3 \mathrm{eV}-\mathrm{ZrO}_{2}\right)$ and niobium oxide $\left(207.6 \mathrm{eV}-\mathrm{Nb}_{2} \mathrm{O}_{5}\right)$ for sample without the addition of $\mathrm{ZnO}$ (Figure 5). Whereas, these oxides were not detected on the surface of TiZr-350-ZnO sample (Figure 6).

Binding energies of zinc oxide $(\mathrm{ZnO}-1022.1 \mathrm{eV})$ and $(1023.3 \mathrm{eV})$ were observed. For the TiZr-350 sample, the high resolution XPS spectra of the P2p, Ca2p exhibited dominant peaks located at $133.4 \mathrm{eV}$ and 347.6, corresponding to calcium phosphate functional groups. The peak at $531.9 \mathrm{eV}$ for the O1s spectrum came from the $\mathrm{PO}_{4}{ }^{3-}$ lattice. In the case of the samples with incorporated $\mathrm{ZnO}$, characteristic binding energies were also observed for phosphate groups $(133.4 \mathrm{eV}-\mathrm{P} 2 \mathrm{p} 3 / 2,531.6 \mathrm{eV}-\mathrm{O} 1 \mathrm{~s})$ and also for metaphosphate groups $(134.3 \mathrm{eV}-\mathrm{P} 2 \mathrm{p} 3 / 2,532.7 \mathrm{eV}-\mathrm{O} 1 \mathrm{~s})$ of a predominant nature. We can suppose that phosphorus compounds in the presence of $\mathrm{ZnO}$ precursors were preferentially formed during layer formation. Therefore, no typical binding energies, characteristic for calcium phosphates were detected on the sample surface. Only the presence of $\mathrm{Ca}-\mathrm{Cl}$ bonds was found. These results correlated well with EDX analysis. Presence of $\mathrm{Cl}$ could be connected with the $\mathrm{ZnO}$ nanoparticle synthesis procedure.
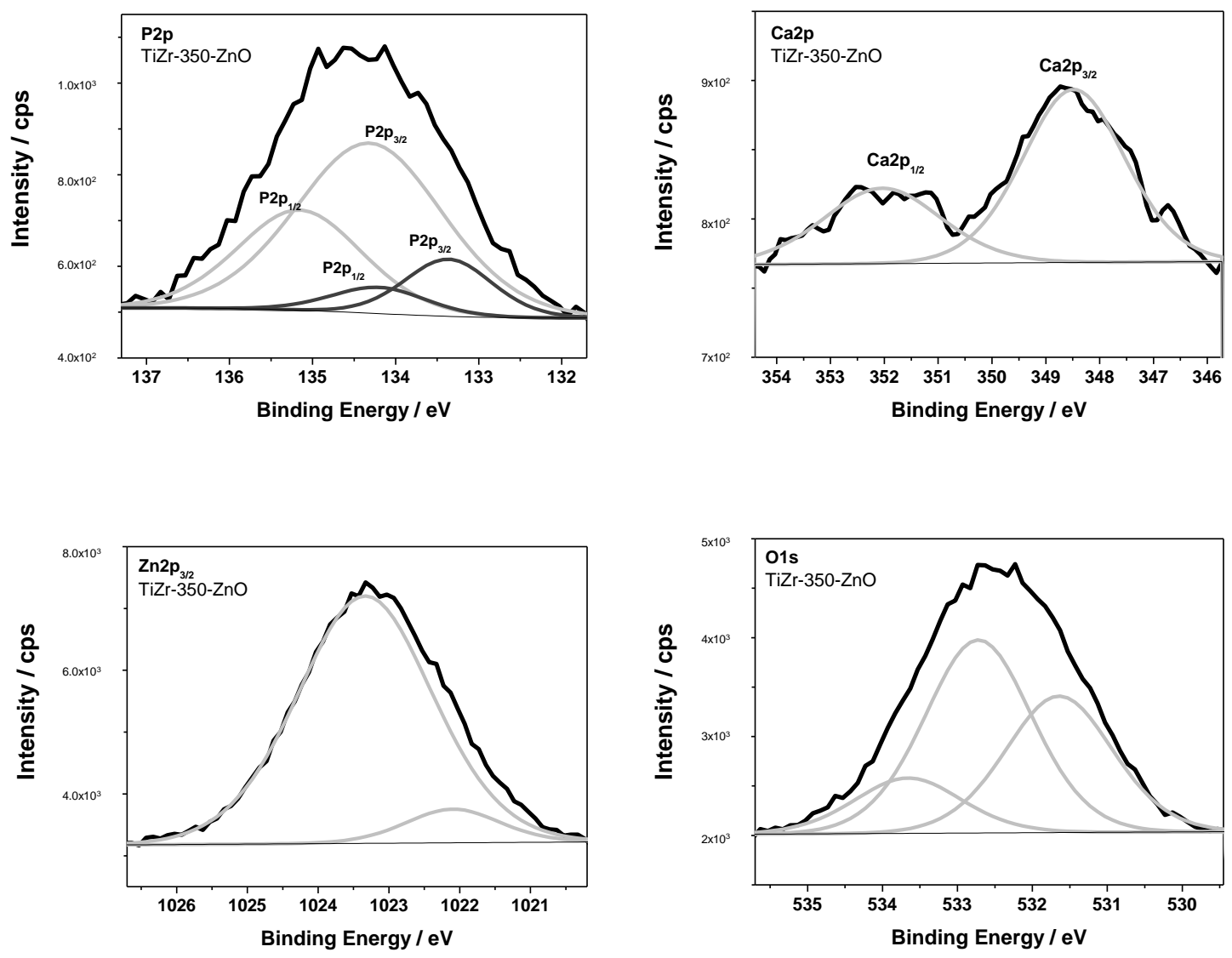

Figure 6. The high resolution XPS spectra after the deconvolution procedure, sample TiZr-350-ZnO.

Normalized photoluminescence (PL) spectra of ZnO-incorporated oxide coatings are shown in Figure 7. PEO treated samples without $\mathrm{ZnO}$ incorportion showed broad asymmetric peak, centered at $524 \mathrm{~nm}$. The observed peak corresponded to $\mathrm{TiO}_{2}$ emission [33]. The observed emission was related to oxygen vacancies and self-trapped excitons [34]. After the PEO process with $\mathrm{ZnO}$ nanoparticles the emission spectra changed. Red shift of emission peak from 524 to $530-536 \mathrm{~nm}$ was observed. New peak 
at $379 \mathrm{~nm}$ appeared in $\mathrm{ZnO}$-incorporated oxide coatings. It is known that $\mathrm{ZnO}$ has two emission bands: UV (375-384 $\mathrm{nm})$, related to excitons, and visible (430-700 nm), related to structure defects [35]. The changes of PL spectra after $\mathrm{ZnO}$ incorporation showed the formed $\mathrm{ZnO}$ nanostructures on the sample's surface. For instance, new UV peek at $379 \mathrm{~nm}$ corresponded to exciton emission of $\mathrm{ZnO}$. Red shift of visible emission pointed to photoluminescence from $\mathrm{ZnO}$ defects (oxygen vacancies) [36]. The ratio between UV and visible emission pointed to crystallinity and defect concentrations in the $\mathrm{ZnO}$. This ratio decreased with increase of limited voltage in the PEO process. According to EDX Zn concentration increased with enhancement of applied voltage. However, increase of the PEO voltage stimulated forming of defects in $\mathrm{ZnO}$, which might influence other properties, such as contact angle and biocompatibility.

Table 2. The XPS data evaluated from the deconvolution of Ti2p, Zr3d, Nb3d, Zn2p, P2p, Ca2p, O1s XPS spectra recorded for the TiZr-350 and TiZr-350-ZnO samples.

\begin{tabular}{|c|c|c|c|c|c|c|c|c|}
\hline \multirow{2}{*}{ Samples } & \multicolumn{7}{|c|}{ Binding Energy (BE)/eV } & \multirow{2}{*}{ Chemical Bonds } \\
\hline & $\mathrm{Ti}^{2} \mathrm{p}_{3 / 2}$ & $\mathrm{Zr} 3 \mathrm{~d}_{5 / 2}$ & $\mathrm{Nb}_{3} \mathrm{~d}_{5 / 2}$ & $\mathrm{Zn} 2 \mathrm{p}_{3 / 2}$ & $\mathbf{P} 2 \mathrm{p}_{3 / 2}$ & $\mathrm{Ca} 2 \mathrm{p}_{3 / 2}$ & O1s & \\
\hline \multirow{4}{*}{ TiZr-350 } & 458.8 & & & & & & 531.1 & $\mathrm{Ti}-\mathrm{O}\left(\mathrm{TiO}_{2}\right)$ \\
\hline & & 183.3 & & & & & 531.1 & $\mathrm{Zr}-\mathrm{O}\left(\mathrm{ZrO}_{2}\right)$ \\
\hline & & & 207.6 & & & & 531.1 & $\mathrm{Nb}-\mathrm{O}\left(\mathrm{Nb}_{2} \mathrm{O}_{5}\right)$ \\
\hline & & & & & 133.4 & 347.6 & 531.9 & calcium phophates \\
\hline \multirow{5}{*}{ TiZr-350-ZnO } & & & & 1022.1 & & & & $\mathrm{Zn}-\mathrm{O}(\mathrm{ZnO})$ \\
\hline & & & & 1023.3 & & & & $\mathrm{ZnO}$ precursor \\
\hline & & & & & 133.4 & & 531.6 & phosphate $\left[\mathrm{PO}_{4}\right]^{3-}, \mathrm{Zn}-\mathrm{O}$ \\
\hline & & & & & 134.3 & & 532.7 & metaphosphate $\left[\mathrm{PO}_{3}\right]^{-}$ \\
\hline & & & & & & 348.5 & & $\mathrm{Ca}-\mathrm{Cl}\left(\mathrm{CaCl}_{2}\right)$ \\
\hline
\end{tabular}

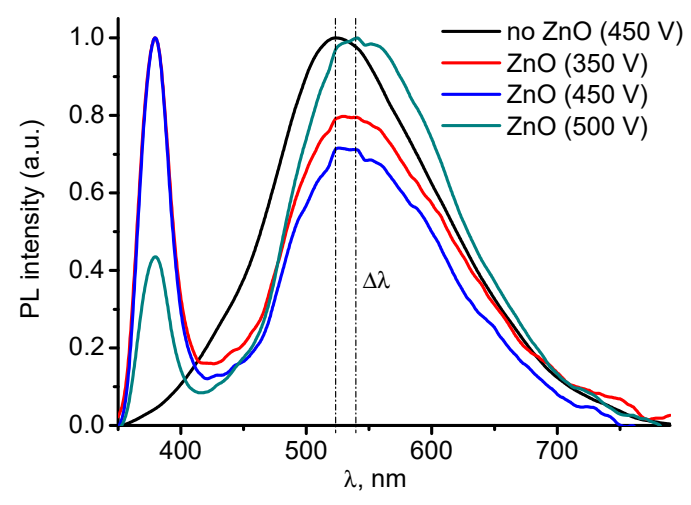

Figure 7. Normalized photoluminescence spectra of $\mathrm{ZnO}$-incorporated oxide coatings on TiZrNb alloy.

Contact angle (CA) is an essential parameter of medical implant surface due to interaction with biological fluids. The hydrophilic surface is favorable for cell attachment but in the same case for bacteria colonization. And vice-versa-pure bacteria attachment to a hydrophobic surface is accompanied by low cytocompatibility [37]. The CA of non-treated TiZr surface was $93.6 \pm 4.90$ and significantly decreased after PEO, up to $21.1 \pm 3.70$ at $450 \mathrm{~V}$ (Figure 8 ). High wettability may play a significant role in biocompatibility during implantation due to fast surface protein absorption after blood-implant contact. The addition of ZnO NPs to electrolyte caused CA shift to hydrophobic values-from $58.2 \pm 6.30$ at $350 \mathrm{~V}$ to $123.1 \pm 14.20$ at $450 \mathrm{~V}$. Antifouling properties of hydrophobic surface could induce additional antibacterial effects. On other hand, it could decrease cell attachment to the surface. 


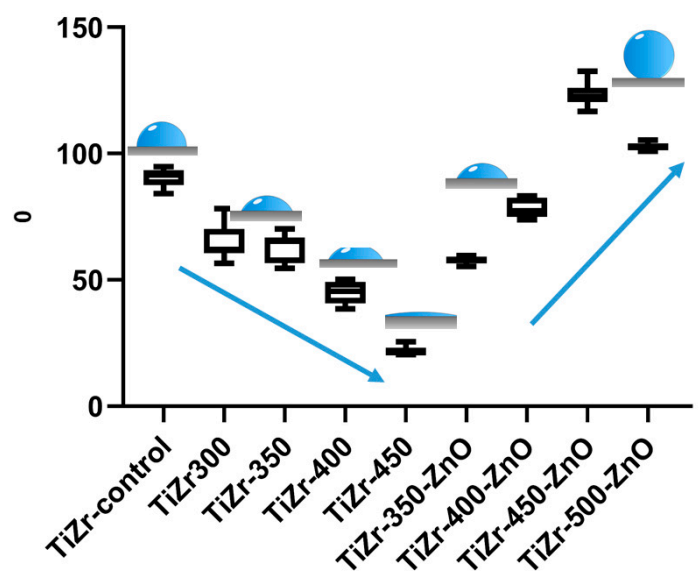

Figure 8. Contact angle distribution of TiZr alloys after treatment in different solution. Blue arrow demonstrates trends in $\mathrm{Ca}\left(\mathrm{H}_{2} \mathrm{PO}_{2}\right)_{2}$ electrolyte bath and with $\mathrm{ZnO}$ NPs.

\subsection{Cell Culture}

Titanium and its alloys demonstrated high biocompatibility and ability to support cell proliferation $[5,7,17]$. Our experiment showed appropriate cell adhesion on day 1 for non-modified TiZrNb alloy surface with next cell proliferation—the viability rate rich $66.8 \pm 4.7 \%$ at day 7 (Figure 9). Ceramic coatings formed at 400 and $450 \mathrm{~V}$ in $\mathrm{Ca}\left(\mathrm{H}_{2} \mathrm{PO}_{2}\right)_{2}$ electrolyte demonstrated significantly higher cell attachment at first day. This relates to low contact angle providing higher level of protein absorption from culture media. As result, the enhancement of cell attachment capacity for modified surface was observed. All surfaces obtained in the PEO process demonstrated significantly higher cell proliferation compared the non-treated control group (Figure 9). As previously reported, the present in the PEO coatings calcium and phosphorus are osteoinductive agents [32,33]. The sample surface, modified with ZnO NPs did not demonstrate significant difference in cell attachment compared to the control samples, except for the TiZr-350-ZnO one, that was characterized by low contact angle. Only at the 7th day was significant cell proliferation found. However, the cell viability rate was still below the level obtained for samples anodized in the $\mathrm{Ca}\left(\mathrm{H}_{2} \mathrm{PO}_{2}\right)_{2}$ electrolyte. We confirm that $\mathrm{ZnO}$ NPs-contained ceramic oxide coating demonstrated a hydrophobic nature that could affect primary cell attachment. Ca-P coating influenced proliferative activity of attached cells stimulating competitive adsorption of cells and bacteria in clinical situation.
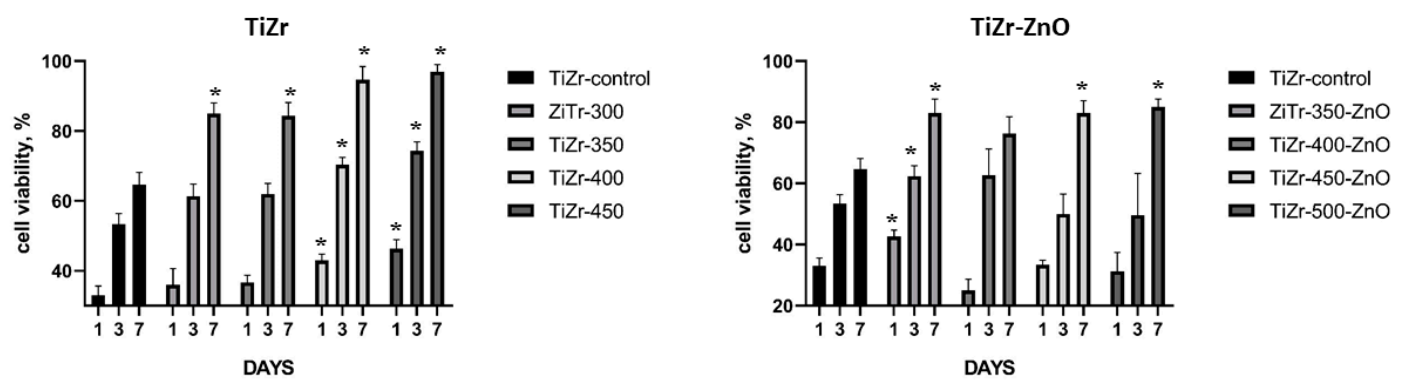

Figure 9. Resazurin reduction assay of U2OS cells cultured on TiZr substrate after $\mathrm{PEO}$ in $\mathrm{Ca}\left(\mathrm{H}_{2} \mathrm{PO}_{2}\right)_{2}$ bath and with ZnO NPs. $\quad(*$ - significant difference $(p \leq 0.05)$ between PEO coated samples and polished control).

\subsection{Bacterial Adhesion Test}

Figure 10 represents that samples with a ceramic oxide layer exhibited higher adhesive activity in comparison to polished control after $2 \mathrm{~h}$ co-cultivation with bacterial suspension. There was no significant difference between TiZr-X and TiZr-X-ZnO samples almost for all subsequent contact times. Nevertheless, all TiZr-X-ZnO samples (except those obtained at $500 \mathrm{~V}$ ), showed significantly 
higher antibacterial activity after $2 \mathrm{~h}$ of incubation. On the other hand, the TiZr-500-ZnO sample exhibited a noticeably higher antibacterial effect against on $S$. aureus in $6 \mathrm{~h}$ of co-cultivation. It can be observed that both types of PEO-treated samples had higher antibacterial activity $(p<0.005)$ in comparison to the polished disks at this time point. The most significant activity was revealed for all $\mathrm{ZnO} \mathrm{NP}$-containing samples; otherwise, better antibacterial performance was demonstrated by TiZr-450-ZnO and TiZr-500-ZnO ones.

The antibacterial properties of $\mathrm{ZnO}$ NPs was realized through the Reactive Oxygen Species (ROS) mechanism [20] and $\mathrm{Zn}$ ions release that leads to bacteria cell membrane penetration with following cell apoptosis [38]. However, high roughness of PEO coated samples induces accelerated adhesion of bacteria [21]. Other possible mechanism that prevent bacteria adhesion is high contact angle that exhibit antifouling machanism [39]. Hence, alloys with a higher level of contact angles exhibited more substantial antibacterial properties against the studied bacteria. They reduced bacteria concentration on their surfaces, preventing biofilm formation.

The revealed antibacterial characteristics of both types of sample surfaces ( $T i Z r-X$ and TiZr-X-ZnO samples) are under the influence of the surface nanotopography. The present work suggests that ZnO NPs may be acceptable for PEO treatment solutions because they did not facilitate bacterial adhesion and considerably developed the antibacterial property of TiZrNb alloys. That is vital for the prevention of chronic inflammatory responses caused by commensal microorganisms as they can stimulate inflammatory cytokines and chemokines, leading to tolerance and active immunity disbalance [40].

A

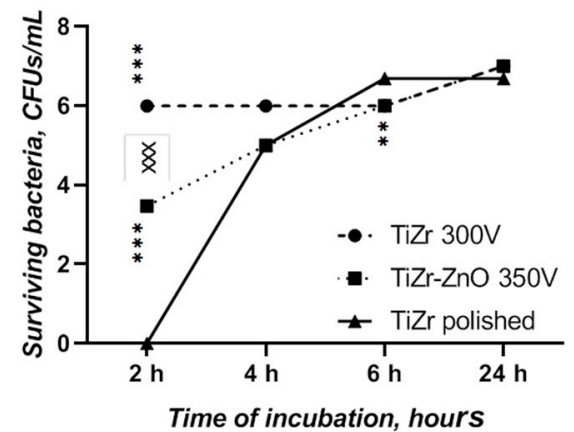

C

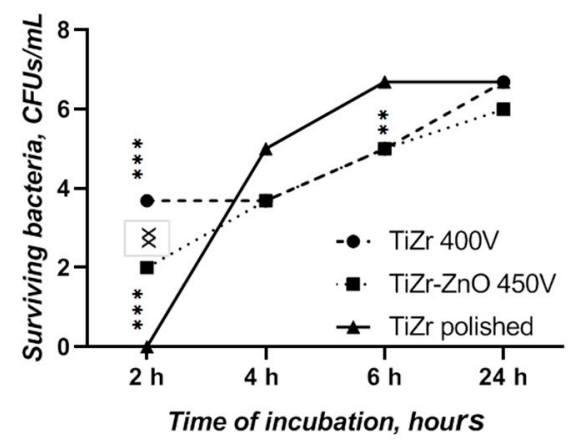

B

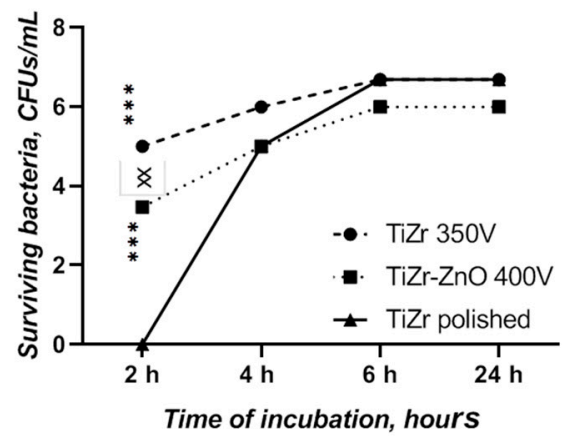

D

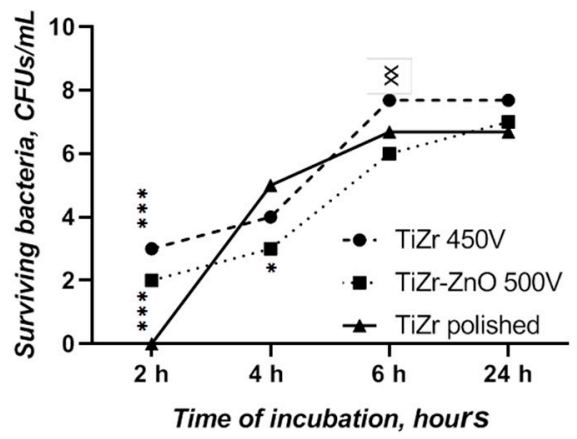

Figure 10. Comparison of the time-dependent adhesion effect of TiZr and TiZr-ZnO samples (A)-samples TiZr-300-ZnO and TiZr-350-ZnO, (B)-TiZr-350-ZnO and TiZr-400-ZnO, (C)-TiZr-400-ZnO and TiZr-450-ZnO, and (D)-TiZr-450-ZnO and TiZr-500-ZnO. *-significant difference $(p \leq 0.05)$ between PEO coated samples and polished control $\left({ }^{* *}-p \leq 0.01\right.$ and $\left.{ }^{* * *}-p \leq 0.001\right)$, $x$-significant difference $(p \leq 0.05)$ between TiZr and TiZr-ZnO samples. 


\section{Conclusions}

Plasma electrolytic oxidation of TiZrNb alloys in a $\mathrm{Ca}\left(\mathrm{H}_{2} \mathrm{PO}_{2}\right)_{2}$ electrolyte with and without $\mathrm{ZnO}$ NPs formed a stable ceramic coating. Oxide layer of ceramic coatings formed in the electrolyte without $\mathrm{ZnO}$ NPs was composed of substrate oxides with incorporated $\mathrm{Ca}$ and P elements, in a form of calcium phosphate. Addition of ZnO NPs to the electrolyte changed chemical composition of the coating with reduction of $\mathrm{Ca}$ and $\mathrm{P}$ concentration and formation of metaphosphates. However a new $\mathrm{ZnO} \mathrm{NP}$ loaded surface provided appropriate environment for osteoblast cell adhesion and exhibited medium grade antibacterial activity.

Author Contributions: Conceptualization, M.P. (Maksym Pogorielov) and W.S.; methodology, M.P. (Maksym Pogorielov), O.M., R.V., and O.O.; validation, K.G., O.P., and O.M.; formal analysis, M.P. (Maksym Pogorielov) and W.S.; investigation, O.O., Y.H., V.K., Y.V., K.G., R.P., O.K., and M.P. (Marcin Pisarek); resources, O.O., Y.H., V.K., R.P., O.K., and M.P. (Marcin Pisarek); data curation, O.O., Y.H., V.K., R.P., Y.V., O.P., O.K., and M.P. (Marcin Pisarek); writing-original draft preparation, O.O., V.K., M.P. (Maksym Pogorielov), K.G., R.V., W.S., and M.P. (Marcin Pisarek); writing - review and editing, M.P. (Maksym Pogorielov) and W.S.; visualization, V.K., M.P., K.G., and O.O.; supervision, W.S. and M.P. (Maksym Pogorielov); project administration, W.S. and M.P. (Maksym Pogorielov); funding acquisition, R.V., W.S. and M.P. (Maksym Pogorielov). All authors have read and agreed to the published version of the manuscript.

Funding: This research was supported by H2020 Marie Skłodowska-Curie Actions (NanoSurf 777926), grants from the Ministry of Education and Science of Ukraine \#0119U100823), Grant of Ukraine National Research Fund (2020.02/0223) and the Polish Ministry of Science and Higher Education (04/010/BK_20/0124). Viktoriia Korniienko received support from Latvia National Scholarship-2020.

Conflicts of Interest: The authors declare no conflict of interest.

\section{References}

1. Piotrowski, B.; Baptista, A.A.; Patoor, E.; Bravetti, P.; Eberhardt, A.; Laheurte, P. Interaction of bone-dental implant with new ultra low modulus alloy using a numerical approach. Mater. Sci. Eng. C Mater. Biol. Appl. 2014, 1, 151-160. [CrossRef] [PubMed]

2. Wu, D.; Isaksson, P.; Ferguson, S.J.; Persson, C. Young's modulus of trabecular bone at the tissue level: A review. Acta Biomater. 2018, 78, 1-12. [CrossRef] [PubMed]

3. Gepreel, M.A.-H.; Niinomi, M. Biocompatibility of Ti-alloys for long-term implantation. J. Mech. Behav. Biomed. Mater. 2013, 20, 407-415. [CrossRef] [PubMed]

4. Liu, X.; Chen, S.; Tsoi, J.K.H.; Matinlinna, J.P. Binary titanium alloys as dental implant materials-a review. Regen. Biomat. 2017, 4, 315-323. [CrossRef] [PubMed]

5. Maity, T.; Balc1, Ö.; Gammer, C.; Ivanov, E.; Eckert, J.; Prashanth, K.G. High pressure torsion induced lowering of Young's modulus in high strength TNZT alloy for bio-implant applications. J. Mech. Behav. Biomed. Mater. 2020, 103839. [CrossRef]

6. Li, J.; Jansen, J.A.; Walboomers, X.F.; van den Beucken, J.J. Mechanical aspects of dental implants and osseointegration: A narrative review. J. Mech. Behav. Biomed. Mater. 2020, 103. [CrossRef]

7. Nune, K.C.; Misra, R.D.K.; Li, S.J.; Hao, Y.L.; Yang, R. Osteoblast cellular activity on low elastic modulus Ti-24Nb-4Zr-8Sn alloy. Dent. Mater. 2017, 33, 152-165. [CrossRef]

8. Mishchenko, O.; Ovchynnykov, O.; Kapustian, O.; Pogorielov, M. New Zr-Ti-Nb alloy for medical application: Development, chemical and mechanical properties, and biocompatibility. Materials 2020, 13, 1306. [CrossRef]

9. Almas, K.; Smith, S.; Kutkut, A. What is the Best Micro and Macro Dental Implant Topography? Dent. Clin. N. Am. 2019, 63, 447-460. [CrossRef]

10. Pierre, C.; Bertrand, G.; Rey, C.; Benhamou, O.; Combes, C. Calcium phosphate coatings elaborated by the soaking process on titanium dental implants: Surface preparation, processing and physical-chemical characterization. Dent. Mater. 2019, 35, e25-e35. [CrossRef]

11. Füg, A.; Ulm, C.; Tangl, S.; Vasak, C.; Gruber, R.; Watzek, G. Long-term effects of magnetron-sputtered calcium phosphate coating on osseointegration of dental implants in non-human primates. Clin. Oral Implant. Res. 2009, 20, 183-188. [CrossRef] 
12. Choi, S.-H.; Jang, Y.S.; Jang, J.H.; Bae, T.S.; Lee, S.J.; Lee, M.H. Enhanced antibacterial activity of titanium by surface modification with polydopamine and silver for dental implant application. J. Appl. Biomater. Funct. Mater. 2019, 17. [CrossRef] [PubMed]

13. Qing, Y.; Cheng, L.; Li, R.; Liu, G.; Zhang, Y.; Tang, X.; Wang, J.; Liu, H.; Qin, Y. Potential antibacterial mechanism of silver nanoparticles and the optimization of orthopedic implants by advanced modification technologies. Int. J. Nanomed. 2018, 13, 3311-3327. [CrossRef] [PubMed]

14. Chen, P.; Wu, Z.; Leung, A.; Chen, X.; Landao-Bassonga, E.; Gao, J.; Chen, L.; Zheng, M.; Yao, F.; Yang, H.; et al. Fabrication of a silver nanoparticle-coated collagen membrane with anti-bacterial and anti-inflammatory activities for guided bone regeneration. Biomed. Mater. 2018, 13. [CrossRef]

15. Mao, B.-H.; Tsai, J.C.; Chen, C.W.; Yan, S.J.; Wang, Y.J. Mechanisms of silver nanoparticle-induced toxicity and important role of autophagy. Nanotoxicology 2016, 10, 1021-1040. [CrossRef]

16. Hadrup, N.; Sharma, A.K.; Loeschner, K. Toxicity of silver ions, metallic silver, and silver nanoparticle materials after in vivo dermal and mucosal surface exposure: A review. Regul. Toxicol. Pharmacol. 2018, 98, 257-267. [CrossRef]

17. Zhang, Y.; Liu, X.; Li, Z.; Zhu, S.; Yuan, X.; Cui, Z.; Yang, X.; Chu, P.K.; Wu, S. Nano Ag/ZnO-Incorporated Hydroxyapatite Composite Coatings: Highly Effective Infection Prevention and Excellent Osteointegration. ACS Appl. Mater. Interfaces 2018, 10, 1266-1277. [CrossRef]

18. Shen, X.; Hu, Y.; Xu, G.; Chen, W.; Xu, K.; Ran, Q.; Ma, P.; Zhang, Y.; Li, J.; Cai, K. Regulation of the biological functions of osteoblasts and bone formation by Zn-incorporated coating on microrough titanium. ACS Appl. Mater. Interfaces 2014, 6, 16426-16440. [CrossRef]

19. Park, J.K.; Kim, Y.-J.; Yeom, J.; Jeon, J.H.; Yi, G.-C.; Je, J.H.; Hahn, S.K. The topographic effect of zinc oxide nanoflowers on osteoblast growth and osseointegration. Adv. Mater. 2010, 22, 4857-4861. [CrossRef]

20. He, W.; Kim, H.K.; Wamer, W.G.; Melka, D.; Callahan, J.H.; Yin, J.J. Photogenerated charge carriers and reactive oxygen species in $\mathrm{ZnO} / \mathrm{Au}$ hybrid nanostructures with enhanced photocatalytic and antibacterial activity. J. Am. Chem. Soc. 2014, 136, 750-757. [CrossRef]

21. Li, J.; Tan, L.; Liu, X.; Cui, Z.; Yang, X.; Yeung, K.W.K.; Chu, P.K.; Wu, S. Balancing Bacteria-Osteoblast Competition through Selective Physical Puncture and Biofunctionalization of ZnO/Polydopamine/Arginine-Glycine-Aspartic Acid-Cysteine Nanorods. ACS Nano 2017, 11, 11250-11263. [CrossRef] [PubMed]

22. Sowa, M.; Parafiniuk, M.; Mouzêlo, C.; Kazek-Kęsika, A.; Zhidkov, I.S.; Kukharenko, A.I.; Cholakh, S.O.; Kurmaev, E.Z.; Simka, W. DC plasma electrolytic oxidation treatment of gum metal for dental implants. Electrochim. Acta 2019, 302, 10-20. [CrossRef]

23. Rokosz, K.; Hryniewicz, T.; Raaen, S.; Gaiaschi, S.; Chapon, P.; Matýsek, D.; Pietrzak, K.; Szymańska, M.; Dudek, Ł. Metal Ions Supported Porous Coatings by Using AC Plasma Electrolytic Oxidation Processing. Materials 2020, 13, 3838. [CrossRef] [PubMed]

24. Rokosz, K.; Hryniewicz, T.; Dudek, Ł. Phosphate Porous Coatings Enriched with Selected Elements via PEO Treatment on Titanium and Its Alloys: A Review. Materials 2020, 13, 2468. [CrossRef] [PubMed]

25. Kazek-Kęsik, A.; Krok-Borkowicz, M.; Dercz, G.; Donesz-Sikorska, A.; Pamuła, E.; Simka, W. Multilayer coatings formed on titanium alloy surfaces by plasma electrolytic oxidation-electrophoretic deposition methods. Electrochim. Acta 2016, 204, 294-306. [CrossRef]

26. Korniienko, V.; Oleshko, O.; Husak, Y.; Deineka, V.; Holubnycha, V.; Mishchenko, O.; Kazek-Kęsik, A.; Jakóbik-Kolon, A.; Pshenychnyi, R.; Leśniak-Ziółkowska, K.; et al. Formation of a Bacteriostatic Surface on ZrNb Alloy via Anodization in a Solution Containing Cu Nanoparticles. Materials 2020, 13, e3913. [CrossRef]

27. Oleshko, O.; Liubchak, I.; Husak, Y.; Korniienko, V.; Yusupova, A.; Oleshko, T.; Banasiuk, R.; Szkodo, M.; Matros-Taranets, I.; Kazek-Kęsik, A.; et al. In Vitro Biological Characterization of Silver-Doped Anodic Oxide Coating on Titanium. Materials 2020, 13, 4359. [CrossRef]

28. Oleshko, O.; Deineka, V.; Husak, Y.; Korniienko, V.; Mishchenko, O.; Holubnycha, V.; Pisarek, M.; Michalska, J.; Kazek-Kęsik, A.; Jakóbik-Kolon, A.; et al. Ag Nanoparticle-Decorated Oxide Coatings Formed via Plasma Electrolytic Oxidation on ZrNb Alloy. Materials 2019, 12, 3742. [CrossRef]

29. Jian, Y.T.; Yang, Y.; Tian, T.; Stanford, C.; Zhang, X.P.; Zhao, K. Effect of pore size and porosity on the biomechanical properties and cytocompatibility of porous NiTi alloys. PLoS ONE 2015, 10. [CrossRef]

30. Kujala, S.; Ryhänen, J.; Danilov, A.; Tuukkanen, J. Effect of porosity on the osteointegration and bone ingrowth of a weight-bearing nickel-titanium bone graft substitute. Biomaterials 2003, 24, 4691-4697. [CrossRef] 
31. Lee, D.J.; Kwon, J.; Kim, Y.-I.; Wang, X.; Wu, T.-J.; Lee, Y.-T.; Kim, S.; Miguez, P.; Ko, C.-C. Effect of pore size in bone regeneration using polydopamine-laced hydroxyapatite collagen calcium silicate scaffolds fabricated by 3D mould printing technology. Orthod. Craniofacl. Res. 2019, 22, 127-133. [CrossRef] [PubMed]

32. Rey, C.; Combes, C.; Drouet, C.; Grossin, D. 1.111-Bioactive Ceramics: Physical Chemistry. Elsevier 2011, 1, 187-281. [CrossRef]

33. Nada, A.A.; Rouby, W.M.A.E.; Bekheet, M.F.; Antuch, M.; Weber, M.; Miele, P.; Viter, R.; Roualdes, S.; Millet, P.; Bechelany, M. Highly textured boron/nitrogen co-doped TiO2 with honeycomb structure showing enhanced visible-light photoelectrocatalytic activity. Appl. Surf. Sci. 2020, 505. [CrossRef]

34. Viter, R.; Tereshchenko, A.; Smyntyna, V.; Ogorodniichuk, J.; Starodub, N.; Yakimova, R.; Khranovskyy, V.; Ramanavicius, A. Toward development of optical biosensors based on photoluminescence of $\mathrm{TiO} 2$ nanoparticles for the detection of Salmonella. Sens. Actuators B Chem. 2017, 252, 95-102. [CrossRef]

35. Fedorenko, V.; Viter, R.; Mrówczyński, R.; Damberga, D.; Coy, E.; Iatsunskyi, I. Synthesis and photoluminescence properties of hybrid 1D core-shell structured nanocomposites based on ZnO/polydopamine. RSC Adv. 2020, 10, 29751-29758. [CrossRef]

36. Damberga, D.; Viter, R.; Fedorenko, V.; Iatsunskyi, I.; Coy, E.; Graniel, O. Photoluminescence Study of Defects in ZnO-Coated Polyacrylonitrile Nanofibers. J. Phys. Chem. C 2020, 124, 9434-9441. [CrossRef]

37. Menzies, K.L.; Jones, L. The impact of contact angle on the biocompatibility of biomaterials. Optom. Vis. Sci. 2010, 87, 387-399. [CrossRef]

38. Noimark, S.; Weiner, J.; Noor, N.; Allan, E.; Williams, C.K.; Shaffer, M.S.P.; Parkin, I.P. Dual-Mechanism Antimicrobial Polymer-ZnO Nanoparticle and Crystal Violet-Encapsulated Silicone. Adv. Funct. Mater. 2015, 25, 1367-1373. [CrossRef]

39. Forson, A.M.; van der Mei, H.C.; Sjollema, J. Impact of solid surface hydrophobicity and micrococcal nuclease production on Staphylococcus aureus Newman biofilms. Sci. Rep. 2020, 10, 12093. [CrossRef]

40. Chino, T.; Santer, D.M.; Giordano, D.; Chen, C.; Li, C.; Chen, C.H.; Darveau, R.P.; Clark, E.A. Effects of oral commensal and pathogenic bacteria on human dendritic cells. Oral Microbiol. Immunol. 2009, 24, 96-103. [CrossRef]

Publisher's Note: MDPI stays neutral with regard to jurisdictional claims in published maps and institutional affiliations.

(C) 2020 by the authors. Licensee MDPI, Basel, Switzerland. This article is an open access article distributed under the terms and conditions of the Creative Commons Attribution (CC BY) license (http://creativecommons.org/licenses/by/4.0/). 